\title{
ENDEREÇOS ÚTEIS NA INTERNET
}

A partir deste número, Comunicação \& Educação, passará a publicar, na seção Boletim Bibliográfico, Endereços Úteis na Internet. Esta é uma seleção de endereços eletrônicos com síntese comentada sobre o que oferece cada site indicado. A inteção é dar algumas dicas para pesquisa, bem como oferecer informações para uma navegação com resultados relevantes.

\section{www.usp.br}

Este é o site da Universidade de São Paulo. Nele o leitor poderá navegar por uma infinidade de páginas organizadas nos links: Unida$\underline{\text { des, }}$ onde se encontram as faculdades, institutos, núcleos de pesquisa, órgãos especializados e administração; Graduação, aí são encontradas informações sobre os cursos, como proceder para ingresso, Fuvest e informações gerais; Pós-Graduação, neste link obtêm-se informações sobre os cursos de pós-graduação, sobre bolsas de estudo e regimentos; Pesquisa, nele obtém-se informações sobre os núcleos e grupos de pes-

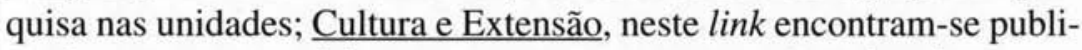
cações, eventos, notícias e reportagens, programação cultural, museus e bibliotecas da USP; liga-se com o jornal, o rádio e a TV USP, bem como a uma série de outros órgãos da imprensa, rádio e televisão naci-

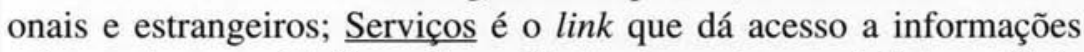
sobre endereços, telefones das unidades, base de especialistas, editais de seleção. Além de tudo isso a página da USP dá acesso à Edusp, ao anuário estatístico da USP e à Coordenadoria de Comunicação Social.

\section{www.prossiga.cnpq.br}

Este é o endereço do Programa de Informação e Comunicação para a Pesquisa (Prossiga) do Conselho Nacional de Pesquisa e Tecnologia - CNPq. É um site que abriga diversas bibliotecas virtuais, informações sobre fomento à ciência e tecnologia, sobre o mercado de trabalho e sobre produção científica. Há também a Escola Virtual Prossiga e um Boletim virtual com fatos, dados e notícias sobre as diferentes áreas do conhecimento. No link Bibliotecas virtuais podemos encontrar: biblioteca virtual Anísio Teixeira, biblioteca virtual Gilberto Freire, biblioteca virtual Carlos Chagas, biblioteca virtual Leite Lopes, biblioteca jurídica virtual, biblioteca virtual de economia, biblioteca virtual de educação a distância, entre outras. 


\section{www.prossiga.br/anisioteixeira}

Este site permite várias entradas. A tradicional, a partir de links temáticos, e a navegação através do link Visita guiada. Aí uma Maria Fumaça nos conduz por uma viagem através da vida e obra do Professor Anísio Teixeira (1900-1971). Através do site pode-se conhecer a infância e a juventude do professor Anísio Teixeira, a Reforma Educacional no antigo Distrito Federal, sua defesa da Educação Pública, o período em que esteve no exílio e depois na Unesco. Anísio Teixeira tem uma obra extensa, escreveu e traduziu diversos livros e foi o criador do movimento Escola Nova.

\section{www.chateauversailles.com}

É o endereço virtual do Palácio de Versalhes, na vila de Versalhes, Paris, França. O velho Palácio de Versalhes foi construído como residência de caça do rei Luís XIII, em 1623. O rei Luís XIV reformulouo totalmente e para lá a corte francesa mudou-se em 1682. O site permite navegar pelos salões do palácio, pelas galerias, pelo quarto do rei e da rainha, admirar sua rica arquitetura, móveis e obras de arte. Além de proporcionar uma bela imagem de seus fantásticos jardins.

\section{www.edutecnet.com.br}

O endereço da Rede de Tecnologia na Educação - Edutecnet permite conhecer mais de perto o debate sobre as novas tecnologias no espaço pedagógico. Oferece um leque amplo de alternativas para pesquisa, leitura, serviços. Traz também extratos de palestras, entrevistas, e um chat para discussão sobre o tema.

\section{www.itaucultural.org.br}

Este endereço oferece uma variedade grande de rotas de navegação. Você pode consultar, on line, um banco de imagens e textos de obras de artes plásticas brasileiras; percorrer as diferentes exposições abrigadas pelo Itaú Cultural; conhecer o acervo, as instituições conveniadas, os projetos on line, a programação do mês e ter acesso ao boletim semanal Sala de Imprensa.

\section{www.oficinainforma.com.br}

Este é o endereço do Oficina Informa. Um jornal eletrônico que faz parte do projeto que tem como objetivo reconstruir a imprensa popular no Brasil. Conta com a participação de jornalistas experientes, 
tarimbados pelo exercício do jornalismo investigativo e que participaram de equipes que fizeram importantes jornais da imprensa alternativa brasileira, tais como Opinião, Movimento, Retrato do Brasil e Atenção. Oficina Informa tem edição diária com as seguintes editorias: Ponto de vista, Fatos do mundo e Fatos do Brasil. Abriga ainda a Revista Reportagem, outra iniciativa do projeto, que pretende editar uma grande reportagem todo mês.

\section{www.eca.usp.br/departam/cca/cultext/comueduc/rcabert.htm}

Este é o endereço da revista Comunicação \& Educação, tem como objetivo divulgar as novidades no âmbito do debate sobre comunicação/educação. A revista conta com colaboradores nacionais e internacionais que se debruçam sobre esta interface, enriquecendo a discussão do tema e apontando caminhos. Acessando este site você encontrará um banco de dados com resumo, em português e inglês, de todos os artigos publicados nas revistas de número 1 a 10 . Os artigos estão divididos por temas, autor e título. Também estão disponíveis no site o artigo de Apresentação, o Sumário e o Editorial, atualizados a cada número da revista. Os interessados em assinar Comunicação \& Educação poderão fazê-lo on-line. 